\title{
Article
}

\section{Taurine supplementation to a low protein diet during foetal and early postnatal life restores a normal proliferation and apoptosis of rat pancreatic islets}

\author{
S. Boujendar ${ }^{1}$, B. Reusens ${ }^{1}$, S. Merezak ${ }^{1}$, M.-T. Ahn 1 , E. Arany ${ }^{2}$, D. Hill ${ }^{2}$, C. Remacle ${ }^{1}$ \\ ${ }^{1}$ Laboratory of Cellular Biology, World Health Collaborating Center for the Development of the Endocrine Pancreas, \\ Catholic University of Louvain, Louvain-la-Neuve, Belgium \\ ${ }^{2}$ Lawson Health Research Institute, St. Joseph's Health Care, London Ontario; and Departments of Medicine, \\ Physiology and Paediatrics, University of Western Ontario, Canada
}

\section{Abstract}

Aims/hypothesis. In our previous studies a low protein diet ( $8 \%$ vs $20 \%)$ given during foetal and early postnatal life induced abnormal development of the endocrine pancreas; beta-cell mass and islet-cell proliferation were reduced while apoptosis was increased. Taurine, an important amino acid for development was also reduced in maternal and foetal plasma of protein deficient animals. In this study we aim to evaluate the role of taurine in the alterations observed in rats after a low protein diet.

Methods. Four groups of rats were given either a control, a low protein, or control and low protein diets with $2.5 \%$ taurine in the drinking water. Diets were given to gestating and lactating mothers and to their pups until day 30. Beta and endocrine cell masses were analysed as well as DNA synthesis and apoptosis after taurine supplementation in foetuses and pups.
We also investigated insulin like growth factor-II (IGF-II), inducible nitric oxide synthase (iNOS), and Fas by immunohistochemistry.

Results. In foetuses and neonates nourished with a low protein diet, taurine supplementation restored normal DNA synthesis and apoptosis. This led to adequate beta and endocrine cell mass in pups. In islet cells, immunoreactivity was increased for IGF-II, reduced for Fas and unchanged for iNOS after taurine supplementation.

Conclusion/interpretation. Taurine supplementation to a low protein diet in foetal and early postnatal life prevents the abnormal development of the endocrine pancreas. The mechanisms by which taurine acts on DNA synthesis and apoptosis rate of endocrine cells involve IGF-II, Fas regulation but not iNOS. [Diabetologia (2002) 45:856-866]

Keywords Rats, development, low protein diet, taurine, pancreatic islets, BrdU, TUNEL, IGF-II, Fas.
Clinical epidemiological studies and animal studies, suggest that malnutrition in utero, even over a brief period, could cause irreversible changes in the offspring which could lead to Type II (non-insulindependent) diabetes mellitus, obesity, hypertension

Received: 25 June 2001 / Revised: 8 February 2002

Published online: 8 May 2002

(C) Springer-Verlag 2002

Corresponding author: Dr. C. Remacle, Laboratory of Cellular Biology, World Health Collaborating Center for the Development of the Endocrine Pancreas, Catholic University of Louvain, B-1348 Louvain-la-Neuve, Belgium

Abbreviations: C, Control; LP, low protein; T, taurine; BrdU, bromodeoxyuridine; INOS, inducible nitric oxide synthase; IGF-II, insulin-like growth factor-II and cardiovascular disease in adult life [1]. Poor nutrition in foetal and early life was reported to be detrimental to the development of the beta cell, and therefore could cause Type II diabetes [2, 3].

We have described previously a model of protein deprivation where pregnant rats were fed either a control diet (C) containing $20 \%$ protein or an isocalorific low protein diet (LP) containing $8 \%$ protein throughout gestation. The mean body weight of LP pups was reduced at birth, and the structure and function of the foetal endocrine pancreas were altered $[2,4]$. The mean islet size was reduced after a low protein diet in association with a reduced rate of islet-cell proliferation, and a higher rate of apoptosis $[2,5]$. The islet expression of insulin-like growth factors (IGF-I and IGF-II), which protect against apoptosis while also 
acting as beta-cell mitogens, was also lower in LP foetuses and neonates [5]. The insulin secretory capacity of foetal beta cells was impaired in response to secretagogues [4] and islet blood vessel development was also sensitive to the lack of protein in utero [2]. Some of the alterations observed in LP neonates persist into adulthood, even after resuming a normal diet after birth or after weaning [6]. These observations emphasize the importance of the programming process during development.

Such a deficient protein diet during gestation leads to perturbations in the plasma amino acid profiles of both mothers and foetuses. The availability of particular amino acids, like taurine, was dramatically reduced especially in the foetal serum [7]. Taurine is a sulphurcontaining amino acid which is not incorporated into protein and is not used for energy production. High concentrations of this amino acid are found in animal tissues. The foetus accumulates taurine over the length of pregnancy, and at particularly high rates in the last period of gestation [8]. Taurine is actively transported from mother to foetus across the placental barrier, by a Na+-dependent amino acid transporter [8]. This system was decreased in the placenta of dams fed a low protein diet [9], or in cases of intrauterine growth retardation [10].

Numerous intracellular and extracellular functions have been described, the best known one for taurine is its conjugation with bile acids. Taurine is also involved in the co-ordination of nerve function, stabilisation of the cell membrane, detoxification, anti-oxidant reactions and modulation of osmotic pressure. Several correlations have been made between taurine deficiency and abnormalities such as retinal degeneration, growth retardation and cardiac dysfunction [11, 12]. In the pancreas, taurine is highly concentrated in the islets and stimulates insulin release by foetal beta cells in vitro $[13,14]$. This amino acid has also been reported to have a hypoglycaemic activity [15]. Taurine supplementation in the maternal LP diet (8\% protein vs $20 \%$ ) was able to restore completely the insulin secretory response of cultured foetal islets [16].

This study investigated whether taurine supplementation of the low protein diet of dams during gestation and lactation normalizes the development of the endocrine pancreatic mass, islet cell proliferation, and apoptosis in the offspring.

\section{Materials and methods}

Animals. All procedures were carried out with the approval of the animal ethics committees of the Catholic University of Louvain and the University of Western Ontario. Virgin female Wistar rats were caged with males overnight and copulation was verified next morning by the presence of a vaginal plug. Midnight was arbitrarily considered as the time of mating and day 0 of gestation. In a first series of experiments, where the action of taurine was examined in vitro, two groups of animals were used; a control group (C) was given a $20 \%$ protein diet, and a second group (LP) received an $8 \%$ low protein, isolcalorific diet in which calories were balanced with additional carbohydrate. In a second series of experiments, the effects of taurine were examined in vivo. Four groups of animals were created depending on the diet provided; a $\mathrm{C}$ group, a LP group, a group fed the control diet supplemented with $2.5 \%(\mathrm{w} / \mathrm{v})$ taurine (Sigma Chemical, Bornem, Belgium) in the drinking water $(\mathrm{C}+\mathrm{T})$, and a group which was fed LP diet supplemented with $2.5 \%$ taurine $(\mathrm{LP}+\mathrm{T})$. The diets were given throughout gestation, lactation and until the last day of experimentation (day 30 postnatal). Diets were purchased from Hope Farms (Woerden, Holland), and are devoid of taurine [2]. The animals were maintained at $25^{\circ} \mathrm{C}$ with $12 \mathrm{~h}$ dark-light cycle and had free access to food and water. At the time of birth, litters were reduced to eight pups and were killed at up to 30 days. Taurine supplementation decreased neither the food or water intake [16].

Pregnant mothers or pups were injected subcutaneously with 5-bromo-2-deoxyuridine (BrdU, $50 \mathrm{mg} / \mathrm{Kg}$ bodyweight in sterile saline, Boehringer Mannheim, Germany) 3 hours before they were killed to label newly formed DNA. The pregnant rats from $\mathrm{C}, \mathrm{LP}, \mathrm{C}+\mathrm{T}$ and $\mathrm{LP}+\mathrm{T}$ groups were anaesthetized with pentobarbital ( $55 \mathrm{mg} / \mathrm{Kg}$ bodyweight) on day 21.5 of gestation (F21.5). Foetal blood samples were rapidly collected for insulin and glucose assays via the axillary vessels, with the foeto-maternal circulation being maintained. In pups of 12, 14 and 30 day-old (respectively P12, P14 and P30), blood samples were collected after decapitation. The foetuses and the pups were weighed before their pancreata were removed and weighed. Pancreata were placed in ice-cold fixative (4\% paraformaldehyde (w/v) and $0.2 \%(\mathrm{v} / \mathrm{v})$ glutaraldehyde in $70 \mathrm{mmol} / \mathrm{l}$ phosphate buffered saline, $\mathrm{pH} 7.4$ ) overnight at $4^{\circ} \mathrm{C}$, followed by four washes at $4^{\circ} \mathrm{C}$ in phosphate buffered saline (PBS) over 48 hours.

Culture of foetal islets. Pancreata of 21.5 days-old foetuses from mothers fed either C or LP diet were removed aseptically. The culture technique was slightly modified from that described previously [17]. All the preparation, including the digestion of the pancreatic tissue, was carried out with RPMI 1640 medium (Gibco, Grand Island, N.Y., U.S.A.). The medium was supplemented with $10 \%(\mathrm{v} / \mathrm{v})$ heat-inactivated foetal bovine serum (Gibco) and antibiotics (penicillin $200 \mathrm{U} / \mathrm{ml}$, streptomycin $0.2 \mathrm{mg} / \mathrm{ml}$ ). The final glucose concentration in the culture medium was $11 \mathrm{mmol} / \mathrm{l}$.

The pancreata were minced and digested with collagenase (Sigma, specific activity $381 \mathrm{U} / \mathrm{ml}, 1.6 \mathrm{mg} / \mathrm{ml}$ per 12 pancreata) at $37^{\circ} \mathrm{C}$. Digestion was stopped by the addition of ice-cold medium. After washing, tissue samples were suspended in $10 \mathrm{ml}$ medium and gently stirred at room temperature for $60 \mathrm{~min}$. The digested pancreata were pelleted by centrifugation, and re-suspended in a ratio of one pancreas per $\mathrm{ml}$ of medium. Finally $2 \mathrm{ml}$ of this suspension was distributed in $35 \mathrm{~mm}$ Petri dishes (Falcon 3001; Falcon Plastics, Los Angeles, Calif., USA). The culture dishes were incubated for 6 days at $37^{\circ} \mathrm{C}$, in a humidified atmosphere of $5 \% \mathrm{CO}_{2}$ in air. The culture medium was changed daily after the second day. Taurine at 1.25 or $2.5 \mathrm{mmol} / \mathrm{l}$ was added during the last $48 \mathrm{~h}$ of the culture while $\mathrm{BrdU}(10 \mathrm{mmol} / \mathrm{l})$ was added for the last $24 \mathrm{~h}$ of culture.

Analysis of islet cell DNA synthesis in vitro. For the visualisation of cell DNA synthesis we followed a modified procedure based on the methods of [18] and [19]. Cells were fixed in absolute methanol for $10 \mathrm{~min}$ at $4^{\circ} \mathrm{C}$. DNA was denatured by incubating in $2 \mathrm{~N} \mathrm{HCl}$ for $60 \mathrm{~min}$ at $37^{\circ} \mathrm{C}$, and the acid neutralised by immersing the cells in $0.1 \mathrm{~mol} / \mathrm{l}$ borate buffer, $\mathrm{pH} 8.5$. 
After a series of washes in phosphate buffered saline, cells were incubated with $6 \mathrm{mg} / \mathrm{ml}$ mouse monoclonal anti-BrdU antibody (Boehringer Mannheim, Germany). A FITC conjugated secondary antibody anti (mouse $\mathrm{IgG}$ ) $\mathrm{IgG}$ (DAKO A/S, Denmark) was used at a 1:400 dilution. Islets were incubated for $20 \mathrm{~min}$ with $20 \mathrm{mg} / \mathrm{ml}$ of ethidium bromide to stain total nuclei. Islets were then mounted in a mowiol solution (6 g Glycerol, 2.4 g Polyvinylalcool 88\%, 2.5\% 1,4-diazobicyclo(2.2.2)-octane, $12 \mathrm{ml}$ Tris $0.2 \mathrm{~mol} / \mathrm{l}$ at $\mathrm{pH} 8.5$ ) and observed under a confocal microscope.

Immunohistochemistry was visualised using a confocal laser scanning microscopy system (MRC 1024, BioRad, UK) equipped with argon ion as well as with mixed krypton and argon ion lasers. FITC was excited at $494 \mathrm{~nm}$ and emitted at $520 \mathrm{~nm}$, ethidium bromide was excited at $510 \mathrm{~nm}$ and emitted at $595 \mathrm{~nm}$, this allowed the direct detection of BrdU-positive cells at the green channel and total nuclei at the red channel. Four to five optical sections were collected every $12 \mu \mathrm{m}$ through the entire islet for a total of 1500 to 2000 nuclei in each group studied per culture, for at least three replicate cultures. The number of BrdU-positive cells and total number of islets cells were counted. Cells undergoing DNA synthesis were expressed as a percentage of total islet cells.

Immunohistochemistry. Fixed tissues of $\mathrm{C}, \mathrm{C}+\mathrm{T}, \mathrm{LP}$ and $\mathrm{LP}+\mathrm{T}$ were dehydrated, embedded in paraffin and tissue sections were cut $(7 \mu \mathrm{m})$. Immunohistochemistry was done to localise BrdU, iNOS, Fas, IGF-II and insulin by a modified avidinbiotin peroxidase method [20]. Slides were incubated overnight at $4{ }^{\circ} \mathrm{C}$ in a humidified chamber with either mouse antiiNOS anti-serum (1:50 dilution) (Transduction Laboratories, Lexington, Ky., U.S.A.), hamster anti-Fas antibody (1:500 dilution) (Pharminagen, Ontario, Canada), human anti-IGF-II (1:2000 dilution) (GroPep, Adelaide, Australia), mouse antiBrdU (labelling kit supplied by Zymed Laboratories, San Francisco, Calif., USA), or mouse anti-insulin (1:6000 dilution) (Novo Nordisk, Copenhagen, Denmark). All antisera were diluted in $0.01 \mathrm{~mol} / \mathrm{l}$ PBS ( $\mathrm{pH} 7.5$ ) containing 2\% (w/v) BSA and $0.01 \%(\mathrm{w} / \mathrm{v})$ sodium azide (100 ml per slide). Rabbit antihuman IgG (1:100 dilution) (Sigma, St. Louis, Mo., USA), mouse anti-hamster IgG (1:100 dilution) (Vector Laboratories, Burlingame, Calif., USA) and sheep anti-mouse IgG (1:1500 dilution) (Amersham, Bergrand, Nederland) were used as secondary antibodies. The immunocytochemical staining has been validated in previous studies [5, 20]. In addition, for every immunostaining, simple controls were done by omitting primary antiserum. In each case staining was abolished. Tissue sections were counter-stained with Carrazi's hematoxylin.

Analysis of islet cell apoptosis. Immunohistochemistry was also done to localise apoptotic nuclei on histological sections of pancreas using a TUNEL method. DNA strand breaks were visualised using the in situ cell death detection kit, TMR red (Boehringer Mannheim, Germany). The working procedure was described by others [21]. The main advantage of this kit is the use of tetramethyl-rodhamine-dUTP to directly label DNA strand breaks with red fluorescence after $1 \mathrm{~h}$ of incubation with the enzyme, deoxynucleotidyl transferase (TdT), and the label solution. After a series of washes in phosphate buffered saline, slides were then mounted in mowiol solution containing $50 \mathrm{mg} / \mathrm{ml} \mathrm{DAPI}$, to stain all nuclei and observed using confocal microscopy.

Rhodamine was excited at $505 \mathrm{~nm}$ and emission peaked at $533 \mathrm{~nm}$, while DAPI was excited at $359 \mathrm{~nm}$ and emission peaked at $461 \mathrm{~nm}$. This allows the direct detection of apoptotic cells at the red channel and total nuclei at the blue channel. Three different sections were studied for each of four pancrea- ta at each experimental day analysed, a total of 1000 to 1500 islet nuclei in each pancreas being measured. The number of apoptotic-positive cells was calculated and expressed as percentage of total cell number in each group.

Morphometrical analysis. Pancreatic endocrine mass and beta cell mass were calculated following immunohistochemistry for insulin on sections obtained throughout pancreata of known weight. The area of tissue was measured for three to six different sections per animal (four to five animals per group C, LP, $\mathrm{C}+\mathrm{T}$ and $\mathrm{LP}+\mathrm{T}$ ), and endocrine and beta-cell masses were estimated by calculating respectively the mean area of islets and the cells immunoreactive for insulin per sectional area of pancreas, using NIH-Image 1.56 software in a Reichert Polyvar microscope (Vienna, Austria). These were then expressed per mg of endocrine or beta-cell mass based on the total pancreatic weight. Total islets number in each section was calculated from these measurements and expressed per $\mathrm{mm}^{2}$ of pancreas. Islet size distribution, also calculated from the previous measurements, were compared between groups using a Kolmogorov-Smirnov's test in C, LP, C+T and LP+T animals at foetal day 21.5 and postnatal day 30 .

To quantify the cell proliferation or apoptotic rate and the relative presence of IGF-II, iNOS and Fas, a morphometric analysis was done using a Carl Zeiss transmitted light microscope at a magnification of $\times 250$ or $\times 400$. A Northern Eclipse, version 2.0 morphometric, analysis software (Empix Imaging Co., Mississauga, Ontario, Canada) was used for analyses. The percentage of islet cells immunopositive for each protein was calculated at each age from up to three non-successive sections of each pancreas representing predominantly the head regions. Sections chosen contained at least five islets each and pancreata of five animals were examined for each age. Individual cell area and total areas of immunoreactive cells within islets were circled for image analysis and selected by gray-level threshold. Means were expressed as a percentage of immunoreactivity of the control.

Measurement of insulin and glucose. Fifty microlitres of blood were collected for glucose analysis and precipitated in $500 \mu \mathrm{l}$ $\mathrm{HCLO}_{4}(0.33 \mathrm{~N})$. Glucose concentrations were measured by the glucose oxidase method (Sigma). Plasma was also prepared, and the insulin content measured by RIA (Insik 5p2796; Sorin, Italy) using rat insulin (Novo-Nordisk) for the standard curve. The method allowed the detection of $4 \mathrm{mU} / \mathrm{ml}$ $(0.16 \mathrm{ng} / \mathrm{ml})$ with coefficients of variation within and between assays of $8.2 \%$.

Statistical analysis. Statistical comparisons were made using ANOVA followed by Scheffe's test. A Kolmogorov-Smirnov's two-sample test (asymptotic) was used for islets size distribution in each group. A $p$ value of less than 0.05 was considered statistically significant.

\section{Results}

Effect of taurine on islet cell DNA synthesis in vitro. Control and LP islets were cultured for 6 days and were subsequently challenged for 2 days with taurine ( 1.25 or $2.5 \mathrm{mmol} / \mathrm{l})$. During the final $24 \mathrm{~h}$ of culture, BrdU was added to label newly-synthesized DNA during S-phase of the cell cycle. Islet cell and new DNA synthesis labelling is shown in Fig. 1. Ethidium bromide labels all the nuclei (red) and fluo- 


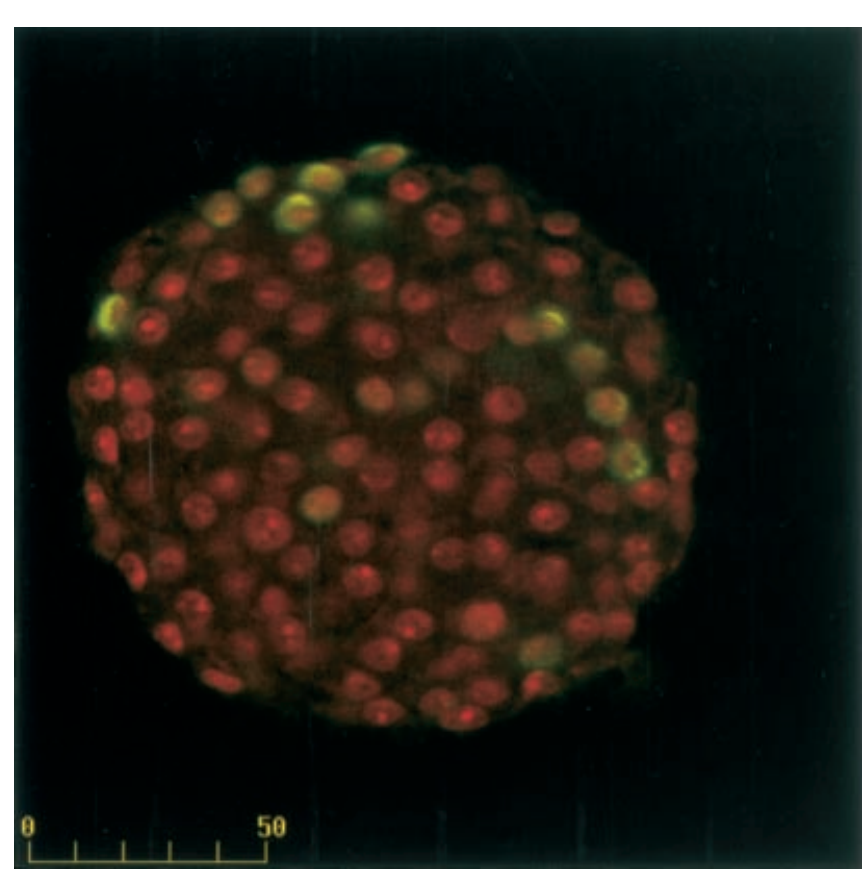

Fig. 1. Confocal micrograph showing a cultured foetal islet. BrdU-positive cells are stained in green and nuclei are stained in red with ethidium bromide. Scale bar $50 \mu \mathrm{m}$

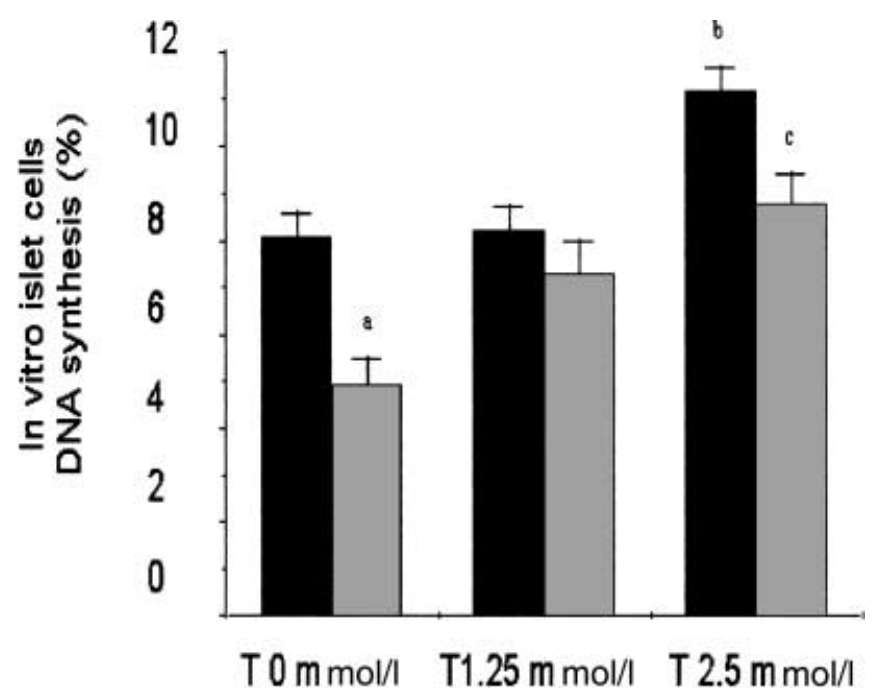

Fig. 2. Effect of taurine addition in vitro on the DNA synthetic rate of $(\mathrm{C}$, black bars) and (LP, grey bars) cultured foetal rat islets. Foetal islets were cultured for 6 days and then treated in the absence ( $\mathrm{T} 0 \mathrm{mmol} / \mathrm{l}$ ) or presence with 1.25 (T $1.25 \mathrm{mmol} / \mathrm{l})$ or $2.5 \mathrm{mmol} / \mathrm{l}(\mathrm{T} 2.5 \mathrm{mmol} / \mathrm{l})$ taurine in the culture medium for 2 days. BrdU was added to the culture medium on the last day of culture. DNA synthesis was quantified by confocal microscopy after adding a monoclonal anti-BrdU antibody. Data are means \pm SEM for three different cultures with at least 2000 cells per group. Differences between means were tested by post-hoc Scheffé's test after ANOVA 1. ${ }^{\mathrm{a}} p<0.01 \mathrm{LP}$ vs $\mathrm{C}$ without taurine. ${ }^{\mathrm{b}} p<0.01 \mathrm{C}$ of $\mathrm{T} 2.5 \mathrm{mmol} / \mathrm{l}$ vs $\mathrm{C}$ of $\mathrm{T} 0 \mathrm{mmol} / \mathrm{l}$. ${ }^{\mathrm{c}} p<0.01 \mathrm{LP}$ of $\mathrm{T} 2.5 \mathrm{mmol} / \mathrm{l} \mathrm{vs} \mathrm{LP}$ of $\mathrm{T} 0 \mathrm{mmol} / \mathrm{l}$
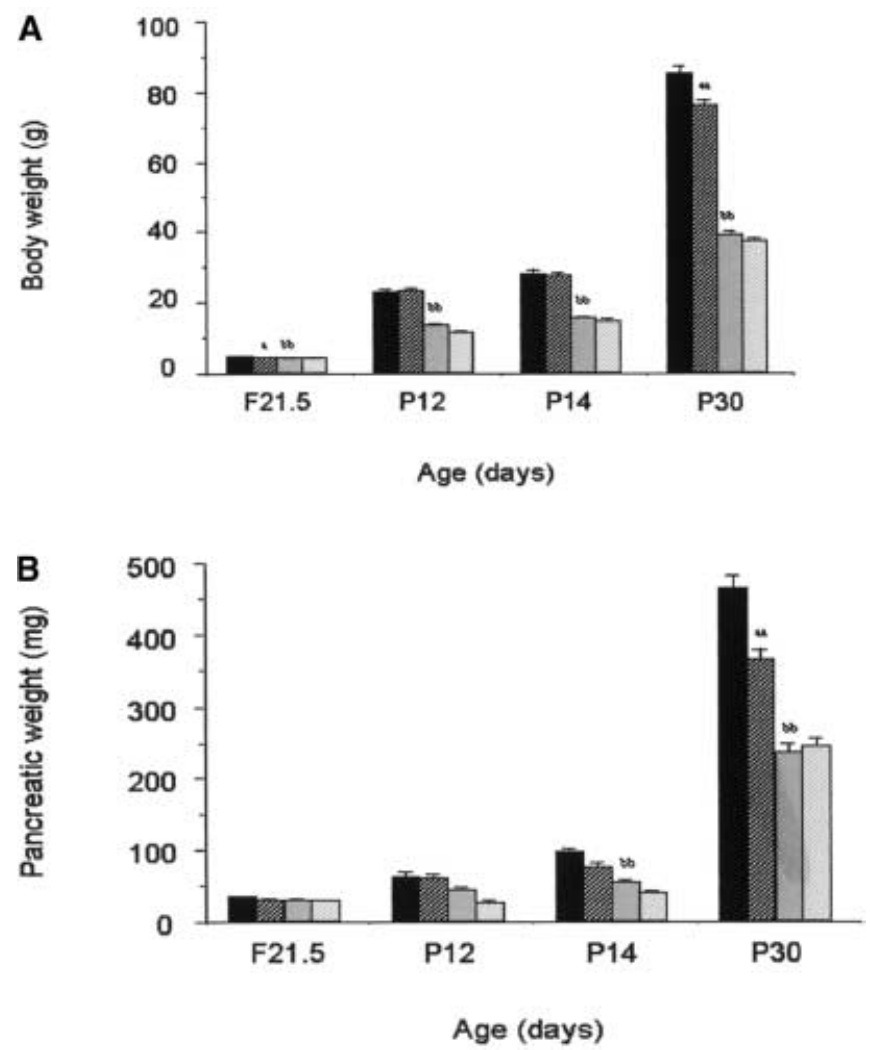

Fig. 3A,B. Effect of taurine supplementation on body (A) and pancreatic weights (B) measured in 21.5 day-old foetuses (F21.5) and 12 (P12), 14 (P14) and 30 (P30) day-old pups. Dams and pups were fed a control (C solid bars), a low protein (LP open bars) $\mathrm{C}+2.5 \%$ taurine $(\mathrm{C}+\mathrm{T}$ hatched bars) or $\mathrm{LP}+2.5 \%$ taurine (LP+T lightly hatched bars) diet from the first day of gestation until postnatal day 30. Data are means \pm SEM of five to six animals per group and age. Differences between means were tested by post-hoc Scheffé's test after ANOVA 1. ${ }^{\mathrm{a}} p<0.05 \mathrm{C}+\mathrm{T}$ vs C. ${ }^{\text {aa }} p<0.01 \mathrm{C}+\mathrm{T}$ vs $\mathrm{C}$. ${ }^{\mathrm{bb}} p<0.01$ LP vs C

rescein labels specifically BrdU-positive cells (green). The percent of cells positive for BrdU is shown in Fig. 2. Islet cell DNA synthesis was lower in the LP group $(p<0.01)$ compared with the control group. DNA synthesis of $\mathrm{C}$ islet cell was higher $(p<0.01)$ when cultured in the presence of $2.5 \mathrm{mmol} / \mathrm{l}$ taurine, while no difference was seen with $1.25 \mathrm{mmol} / \mathrm{l}$ taurine. In the LP group, islets showed an increased DNA synthesis in the presence of taurine in the culture medium, which became significant at $2.5 \mathrm{mmol} / \mathrm{l}$ taurine $(p<0.01)$. At that concentration, islet cell DNA synthesis did not differ from control values.

Effect of taurine supplementation in vivo on body weight, pancreatic weight, plasma insulin and glucose concentrations. Since we found that taurine was able to stimulate islet cell proliferation in vitro, we assessed its actions in vivo during endocrine pancreatic development. Taurine was therefore, added to the drinking water of C and LP mothers from the first day of gestation until weaning, and to pups until 30 days. 
Table 1. Effect of taurine supplementation on insulin and glucose concentrations in serum measured in 21.5-day-old foetuses (F21.5), 12 (P12), 14 (P14), and 30 (P30) day-old pups

\begin{tabular}{llll}
\hline & & Insulin $(\mathrm{mU} / \mathrm{l})$ & Glucose $(\mathrm{mmol} / \mathrm{l})$ \\
\hline F21.5 & C & $216 \pm 35$ & $4.96 \pm 0.21$ \\
& C+T & $106 \pm 23$ & $3.11 \pm 0.39 \mathrm{a}$ \\
& LP & $167 \pm 35$ & $5.13 \pm 0.41$ \\
& LP+T & $162 \pm 26$ & $3.67 \pm 0.38$ \\
P12 & C & $21 \pm 3$ & $7.62 \pm 0.31$ \\
& C+T & $32 \pm 7$ & $7.15 \pm 0.24$ \\
& LP & $14 \pm 3$ & $6.53 \pm 0.30$ \\
& LP+T & $18 \pm 3$ & $5.87 \pm 0.14$ \\
P14 & C & $35 \pm 10$ & $8.08 \pm 0.36$ \\
& C+T & $24 \pm 4$ & $7.51 \pm 0.29$ \\
& LP & $25 \pm 3$ & $6.64 \pm 0.22 \mathrm{~b}$ \\
& LP+T & $28 \pm 8$ & $5.98 \pm 0.13$ \\
P30 & C & $29 \pm 6$ & $7.46 \pm 0.21$ \\
& C+T & $22 \pm 3$ & $6.60 \pm 0.38$ \\
& LP & $25 \pm 1$ & $7.05 \pm 0.29$ \\
& LP+T & $39 \pm 12$ & $6.68 \pm 0.27$
\end{tabular}

Mothers and pups were fed a control (C), a low protein (LP), a control added $2.5 \%$ taurine $(\mathrm{C}+\mathrm{T})$ or a low protein added $2.5 \%$ taurine (LP+T) diet from the first day of gestation until postnatal day 30. Data are means \pm SEM of 5 to 6 animals per group and age. Differences between means were tested by post-hoc Scheffé's test after ANOVA 1. ${ }^{\mathrm{a}} p<0.05 \mathrm{C}+\mathrm{T}$ vs $\mathrm{C}{ }^{\mathrm{b}} p<0.05$ LP vs C

As detailed in our previous work [16], taurine supplementation to the control animals enhanced foetal taurine plasma concentration from $0.32 \mathrm{mmol} / \mathrm{l}$ to $1.07 \mathrm{mmol} / \mathrm{l}$, while in LP animals, it increased from $0.2 \mathrm{mmol} / \mathrm{l}$ to $0.5 \mathrm{mmol} / \mathrm{l}$. Body and pancreatic weights were measured at 21.5 days of gestation (F21.5) as well as postnatal days 12, 14 and 30 (P12, P14 and P30) (Fig. 3A, B). At every age analysed, the body weight of LP animals was lower than that of the control animals $(p<0.01)$ while pancreatic weight was lower only from P14. Taurine supplementation during the perinatal period had no effect on body weight of the offspring or on their pancreatic weight. We noted however, a lower body weight in control foetuses $(p<0.05)$ and a lower body and pancreatic weights in pups at P30 after taurine administration $(p<0.01)$ (Fig. 3A, B).

Plasma insulin concentrations decreased immediately after birth in each of the four groups, and did not differ with maternal diet (Table 1). Correspondingly, blood glucose concentration increased immediately after birth in all four groups. In general, it did not differ between groups. However, taurine administration reduced glycaemia in control animals at F21.5 $(p<0.05)$ (Table 1).

Effect of taurine supplementation in vivo on endocrine mass development. Endocrine and beta-cell mass measured at F21.5 and P30 is reported (Fig. 4A, B). In LP
A
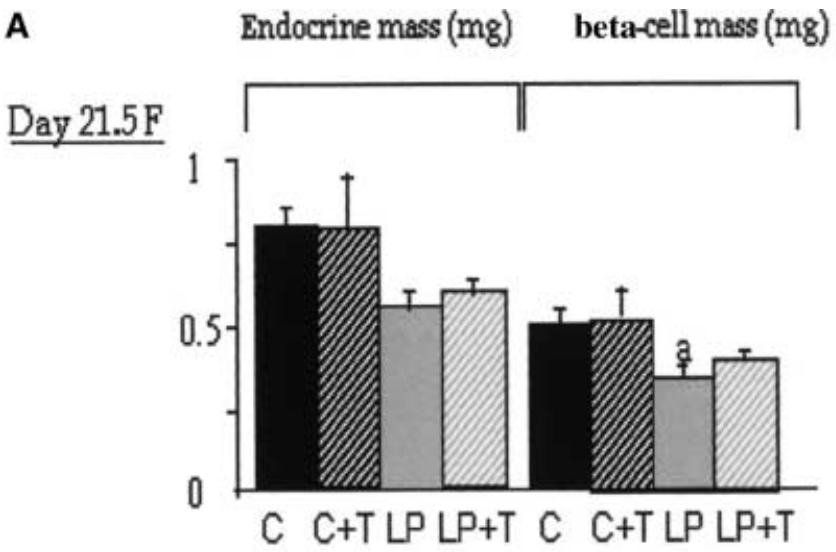

B

\section{Endocrine mass ( $\mathrm{mg}$ ) beta-cell mass (mg)}

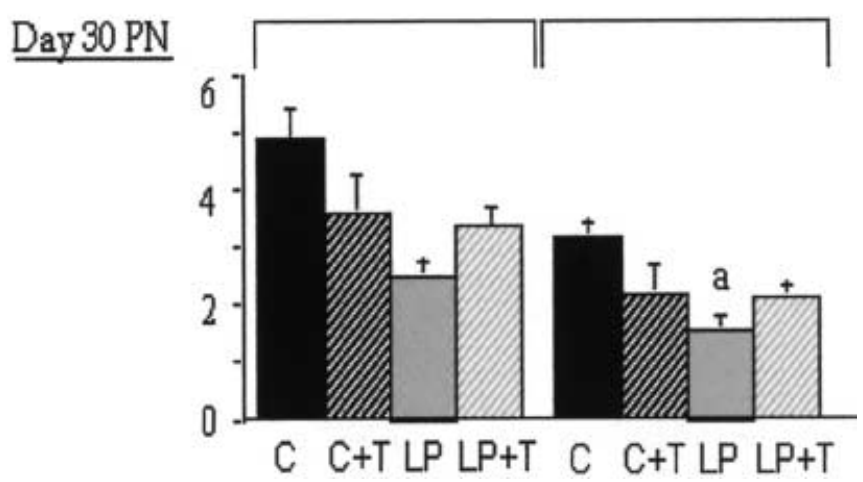

Fig. 4A, B. Effect of taurine supplementation on endocrine and beta cell mass in 21.5-day-old foetuses (F21.5) (A) and 30 day-old pups (P30) (B). Endocrine and beta cell mass were measured in groups having received control $(\mathrm{C})$, a low protein (LP), C+2.5\% taurine $(\mathrm{C}+\mathrm{T})$ or $\mathrm{LP}+2.5 \%$ taurine $(\mathrm{LP}+\mathrm{T})$ diet from the first day of gestation until postnatal day 30. Data are means \pm SEM of five to six animals per group and age. Differences between means were tested by post hoc Scheffé's test after ANOVA 1. ${ }^{a} p<0.01 \mathrm{LP}$ vs C

foetuses, endocrine and beta cell mass per pancreas was slightly lower than in the control foetuses. This decrease was more marked $(p<0.01)$ in 30-day-old pups in which almost $50 \%$ of the endocrine and betacell mass was lost. Taurine supplementation had no effect on endocrine and beta cell mass at the end of foetal life, though at $\mathrm{P} 30, \mathrm{LP}+\mathrm{T}$ animals had recovered endocrine and beta-cell mass comparable to the control animals.

The numerical density of islets in pancreas (Table 2) was higher at F21.5 than at P30 in all four groups. It was slightly higher in LP foetal pancreas and was further increased in postnatal pancreas than in the control animals $(p<0.05)$. Taurine supplementation had no effect on the islets numerical density either in foetuses or pups.

The mean islet size in LP foetuses and pups was decreased compared with the control animals and distribution studies using Kolmogorov-Smirnov test showed more islets of small size in LP animals 
Table 2. Effect of taurine supplementation on islet numerical density and mean islet size in 21.5-day-old foetuses (F21.5) and 30-day-old pups (P30)

\begin{tabular}{llll}
\hline & & $\begin{array}{l}\text { Islets numerical density } \\
\left(\mathrm{mm}^{2}\right)\end{array}$ & $\begin{array}{l}\text { Islets mean size } \\
\left(\mu \mathrm{m}^{2}\right)\end{array}$ \\
\hline F21.5 & $\mathrm{C}$ & $10.06 \pm 0.63$ & 4171 \\
& $\mathrm{C}+\mathrm{T} \cdot$ & $8.93 \pm 0.45$ & 2575 \\
& LP & $12.24 \pm 0.72$ & 1708 \\
& LP+T & $11.24 \pm 0.53$ & 2245 \\
P30 & C & $3.98 \pm 0.26$ & 2826 \\
& C+T & $4.60 \pm 0.39$ & 2276 \\
& LP & $5.99 \pm 0.49$ & 1881 \\
& LP+T & $6.07 \pm 0.31$ & 2490 \\
\hline
\end{tabular}

Mothers and pups were fed a control (C), a low protein (LP), $\mathrm{C}+2.5 \%$ taurine $(\mathrm{C}+\mathrm{T})$ or $\mathrm{LP}+2.5 \%$ taurine $(\mathrm{LP}+\mathrm{T})$ diet from the first day of gestation until postnatal day 30. Data are means \pm SEM of five to six animals per group and age. Differences between means were tested by post-hoc Scheffé's test after Anova 1 a $p<0.05$ vs Control

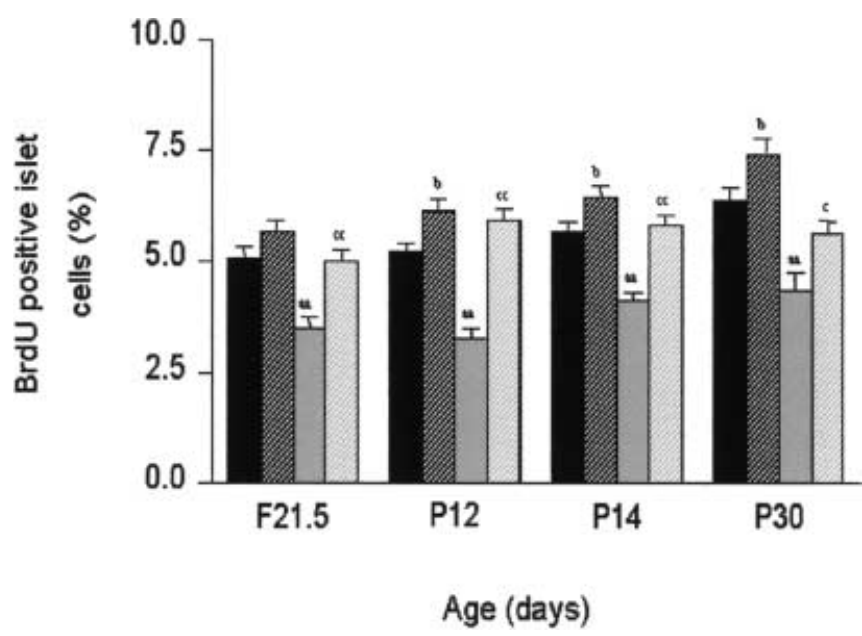

Fig. 5. Percentage of islet cells showing immunoreactivity for BrdU in sections of rat pancreas of 21.5 day-old foetuses (F21.5) and 12 (P12), 14 (P14), and 30 (P30) day-old pups. Mothers were fed a control (C solid bars), a low protein (LP open bars), $\mathrm{C}+2.5 \%$ taurine $(\mathrm{C}+\mathrm{T}$ hatched bars $)$ or $\mathrm{LP}+2.5 \%$ taurine (LP+T lightly hatched bars) diet from the first day of gestation until postnatal day 30. Data are means \pm SEM of three non-successive sections containing each at least five islets. Pancreata of five animals were examined in each group and age. Differences between means were tested by post-hoc Scheffé's test after ANOVA 1. ${ }^{\mathrm{b}} p<0.05 \mathrm{C}+\mathrm{T}$ vs C. ${ }^{\mathrm{c}} p<0.05$ $\mathrm{LP}+\mathrm{T}$ vs LP. ${ }^{a} p<0.01 \mathrm{LP}$ vs C. ${ }^{c c} p<0.01 \mathrm{LP}+\mathrm{T}$ vs LP

(Table 2, $p<0.05$ ). Taurine supplementation had no effect on islet size either in C or in LP foetuses, while in LP pups, islets tended to be larger.

Effect of taurine supplementation in vivo on $C$ and $L P$ islet cell DNA synthesis. After taurine supplementation to the maternal diet, incorporation of BrdU in the islets was measured in vivo (Fig. 5). At each day analysed, a reduction $(p<0.01)$ of the nuclear labelling in- dex between control and LP islets was noted. Taurine supplementation enhanced the nuclear labelling index of $\mathrm{C}$ islet cells after birth $(p<0.05)$. In LP foetuses and neonates, islet cell DNA synthesis was greatly stimulated by taurine supplementation. This increase reached the values of control islet cells, which reflects a complete restoration of nuclear labelling index in LP islets by taurine (Fig. 5).

Effect of taurine supplementation in vivo on $C$ and $L P$ islet cell apoptotic rate. After $2.5 \%$ taurine supplementation in vivo, apoptosis was quantified by TUNEL technique. Figure 6 A shows all of the nuclei labelled with DAPI (green) and TUNEL-positive apoptotic nuclei labelled with rhodamine (red). Figure $6 \mathrm{~B}$ shows the same islet in a consecutive section, immunostained for insulin.

The percent of apoptotic cells is shown (Fig. 7). Apoptotic rate increased rapidly after birth to reach a maximum at P14 in the four groups. LP islets showed a higher apoptotic rate $(p<0.01)$ at each age analysed compared with the control animals. Taurine supplementation lowered the apoptotic rate of control islet cells after birth $(p<0.01)$. In LP foetuses and neonates, islet cell apoptosis was greatly reduced by taurine supplementation. The percentage of apoptosis observed declined to reach approximately the control values (Fig. 7).

Effect of taurine supplementation in vivo on iNOS expression in $C$ and LP islet cells. The proportion of islet area positive for iNOS increased rapidly after birth in all groups with a peak appearing at P12 (Fig. 8). No significant difference was noted between the groups. Taurine supplementation had no effect on the timing or amplitude of the peak of iNOS immunoreactivity.

Effect of taurine supplementation in vivo on Fas presence in $C$ and LP islet cells. The proportion of islet area positive to Fas is reported (Fig. 9). As for apoptosis, we observed a rapid increase of islet cell Fas immunoreactivity after birth with a maximum at P14 in all four groups, and a subsequent decline at P30. The percent of islet cells showing immunoreactivity for Fas was higher $(p<0.01)$ in LP foetuses at P14 and P30 compared with the control animals. After taurine supplementation, the immunoreactivity for Fas in $\mathrm{C}$ islets was lower $(p<0.01)$ at $\mathrm{P} 12$, whereas in LP islets, the immunoreactivity for Fas in the islets was lower $(p<0.01)$ at each age analysed.

Effect of taurine supplementation in vivo on IGF-II presence in $C$ and LP islet cells. We found that the proportion of islet area immunopositive to IGF-II decreased progressively after birth in both $\mathrm{C}$ and LP animals (Fig. 10). Taurine supplementation in vivo stimulated the number of islet cells immunoreactive for IGF II in control islets $(p<0.01)$, but only after 

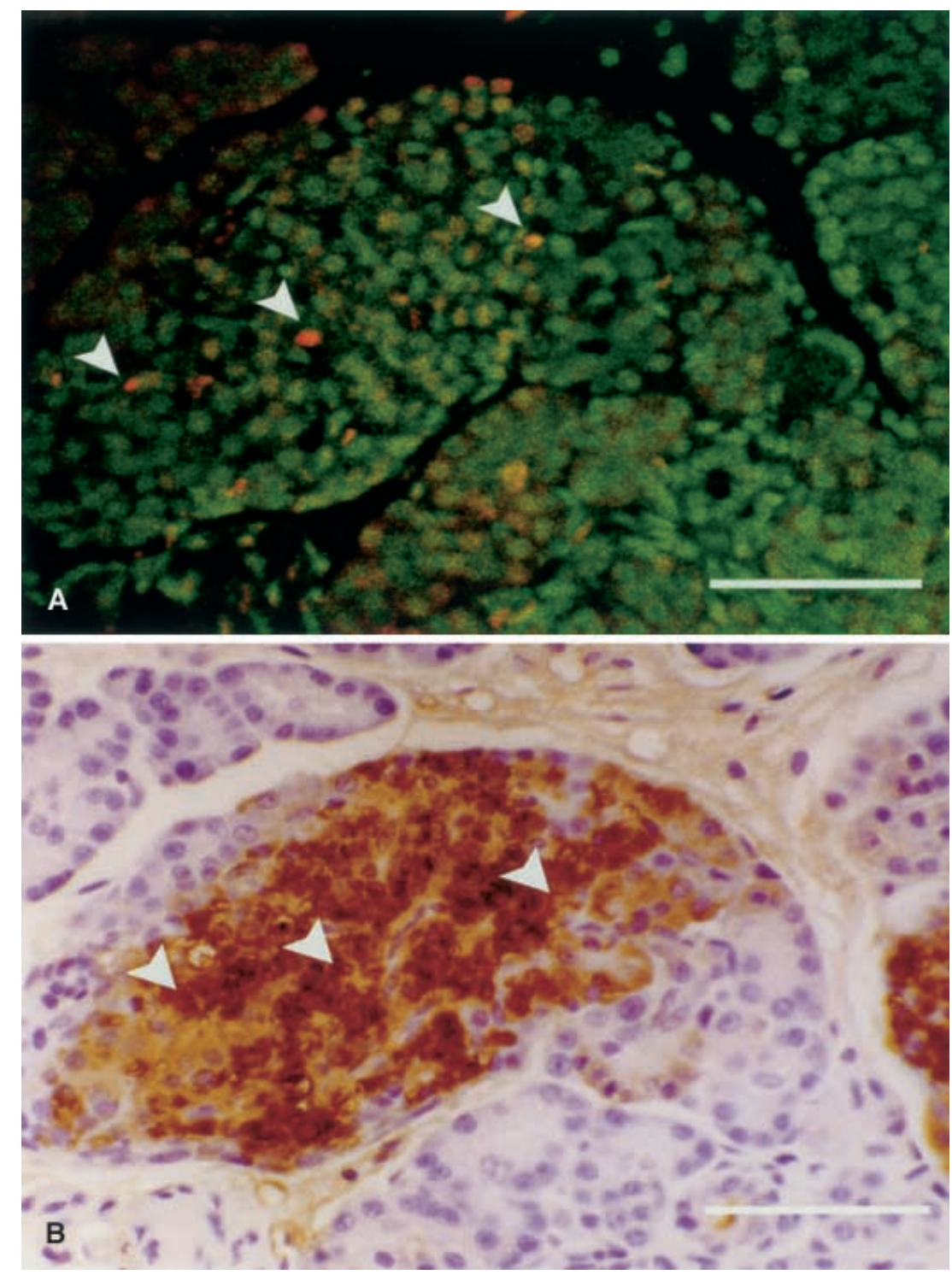

Fig. 6. A Confocal micrograph of a section in a pancreatic islet where all nuclei are labelled with DAPI (green) and TUNEL-positive apoptotic nuclei are labelled with rhodamine (red). B The same islet in a consecutive section, immunostained for insulin. Arrows show three apoptotic nuclei that are located within the beta cell mass. (Scale bar $50 \mu \mathrm{m}$ )

birth, whereas in LP islets, the stimulation by taurine was effective $(p<0.01)$ in both foetal and postnatal islets.

\section{Discussion}

In this study, taurine was provided during gestation and lactation in dams fed a control or low protein diet. This supplementation with $2.5 \%$ taurine in the drinking water did not modify either water or food intake [16]. Dietary taurine supplementation failed to compensate the lower body and pancreatic weights of LP animals. However, we noted a lower body weight in control foetuses which could be related to the hypoglycaemic effect induced by taurine, without modification of the plasma insulin concentrations. We showed that, when islets were cultured from fetuses of mothers supplemented with taurine during their gestation, the control islets stimulated with glucose enhanced their insulin secretion, whereas LP islets showed a complete restoration of their deficient insulin secretion [16]. The effect of taurine on glucose concentrations has been investigated by many authors and conflicting results have been reported. It has been shown that taurine lowers blood glucose concentrations in animals with Type I (insulin-dependent) diabetes mellitus [15]. However, 5\% taurine in the diet had been found ineffective in altering fasting blood glucose concentrations of either control or diabetic mice [22], whereas in diabetic rats, taurine caused no discernible effects [15]. Taurine reduced insulin secretion by adult beta cells in vitro and supplemental taurine has been shown to enhance periph- 


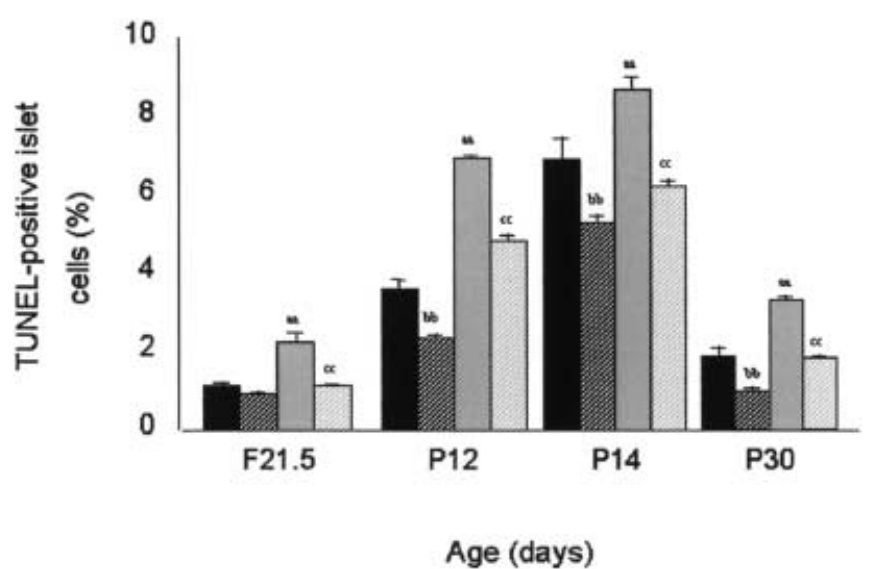

Fig. 7. Percentage of islet cells positive for apoptosis detected by TUNEL test in sections of rat pancreas of 21.5-day-old foetuses (F21.5), 12 (P12), 14 (P14), and 30 (P30) day-old pups. Mothers and pups were fed a control (C solid bars), a low protein (LP open bars), $\mathrm{C}+2.5 \%$ taurine $(\mathrm{C}+\mathrm{T}$ hatched bars) or $\mathrm{LP}+2.5 \%$ taurine (LP+T lightly hatched bars) diet from the first day of gestation until postnatal day 30. Data are means \pm SEM of three non-successive sections containing each at least five islets. Pancreata of five animals were examined in each group and age. Differences between means were tested by post-hoc Scheffé's test after ANOVA 1. aa $p<0.01$ LP vs C. ${ }^{\mathrm{bb}} p<0.01 \mathrm{C}+\mathrm{T}$ vs C. ${ }^{\mathrm{cc}} p<0.01 \mathrm{LP}+\mathrm{T}$ vs LP

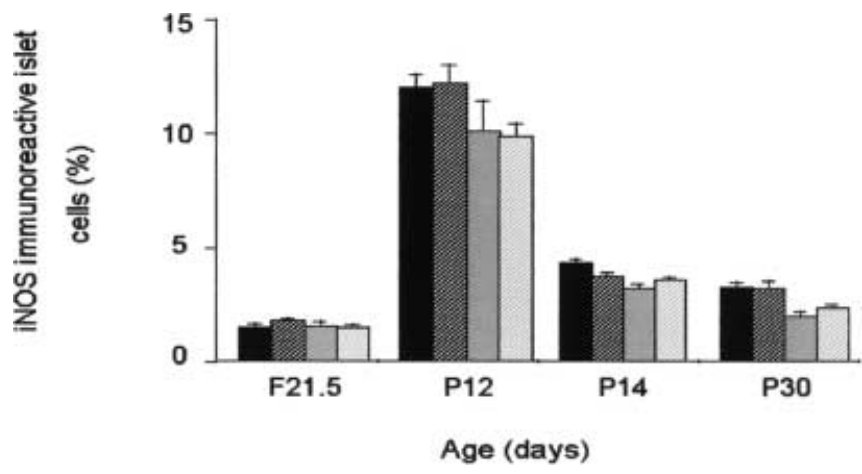

Fig. 8. Proportion of islet area immunoreactive for iNOS in sections of rat pancreas of 21.5-day-old foetuses (F21.5), 12 (P12), 14 (P14), and 30 (P30) day-old pups. Mothers and pups were fed a control (C solid bars), a low protein (LP open bars), $\mathrm{C}+2.5 \%$ taurine ( $\mathrm{C}+\mathrm{T}$ hatched bars) or $\mathrm{LP}+2.5 \%$ taurine (LP+T lightly hatched bars) diet from the first day of gestation until postnatal day 30. Data are means \pm SEM of three nonsuccessive sections containing each at least five islets. Pancreata of five animals were examined in each group and age

eral insulin sensitivity and glucose tolerance in animals $[15,23]$.

In agreement with our previous reports [5, 2], the mean endocrine and beta-cell mass per pancreas is dramatically reduced in LP pups at 30 days of age. LP pancreata showed a lower islet size with more numerous islets. Taurine supplementation restored endocrine and beta-cell mass in LP pups. It also caused a shift in the islet size of these LP animals, islets being larger while their numerical density did not change. These

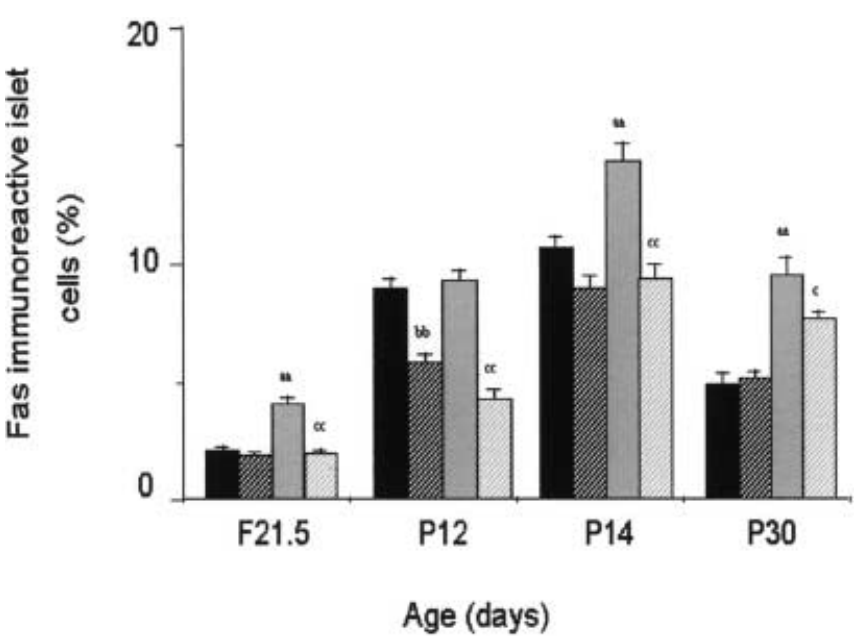

Fig. 9. Proportion of islet area immunoreactive for Fas in sections of rat pancreas of 21.5-day-old fetuses (F21.5), 12 (P12), 14 (P14), and 30 (P30) day-old pups. Mothers and pups were fed a control (C solid bars), a low protein (LP open bars), $\mathrm{C}+2.5 \%$ taurine $(\mathrm{C}+\mathrm{T}$ hatched bars) or $\mathrm{LP}+2.5 \%$ taurine (LP+T lightly hatched bars) diet from the first day of gestation until postnatal day 30. Data are means \pm SEM of three nonsuccessive sections containing each at least five islets. Pancreata of five animals were examined in each group and age. Differences between means were tested by post-hoc Scheffé's test after ANOVA 1. ${ }^{c} p<0.05$ LP+T vs LP. aa $p<0.01$ LP vs C. ${ }^{\mathrm{bb}} p<0.01 \mathrm{C}+\mathrm{T}$ vs $\mathrm{C}^{\mathrm{cc}} p<0.01 \mathrm{LP}+\mathrm{T}$ vs LP

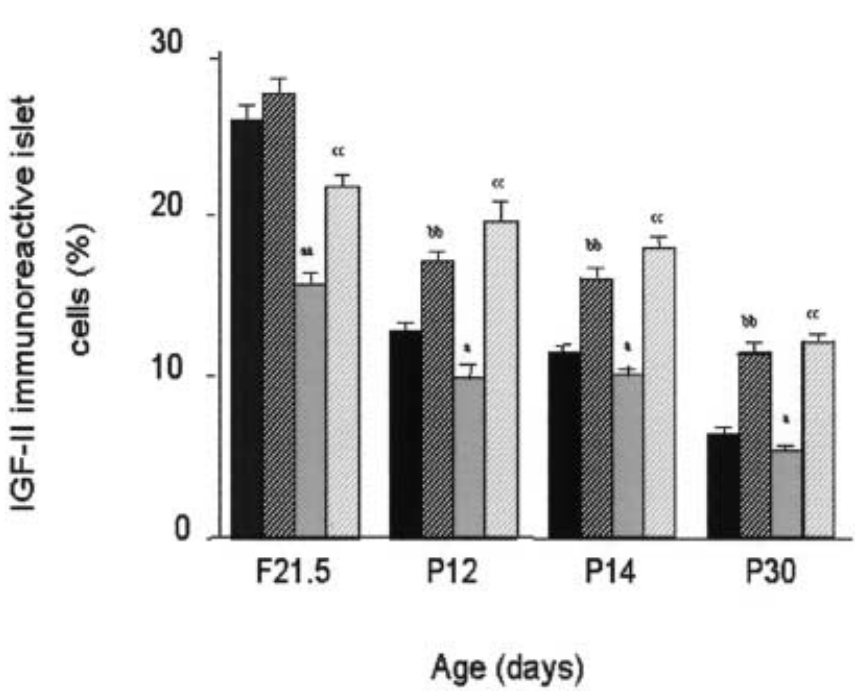

Fig. 10. Proportion of islet area immunoreactive for IGF-II in sections of rat pancreas of 21.5-day-old foetuses (F21.5), 12 (P12), 14 (P14), and 30 (P30) day-old pups. Mothers and pups were fed a control (C solid bars), a low protein (LP open bars $), \mathrm{C}+2.5 \%$ taurine $(\mathrm{C}+\mathrm{T}$ hatched bars $)$ or $\mathrm{LP}+2.5 \%$ taurine (LP+T open bars) diet from the first day of gestation until postnatal day 30 . Data are means \pm SEM of three non-successive sections containing each at least five islets. Pancreata of five animals were examined in each group and age. Differences between means were tested by post-hoc Scheffé's test after ANOVA 1. a $p<0.05$ LP vs C. aa $p<0.01$ LP vs C. ${ }^{b b} p<0.01$ $\mathrm{C}+\mathrm{T}$ vs C. ${ }^{\mathrm{cc}} p<0.01 \mathrm{LP}+\mathrm{T}$ vs LP 
results suggest clearly an action of taurine on replication of islet cells rather than on neogenesis.

The effect of amino acids on beta-cell growth has already been described in vitro [24]. We highlight a mitogenic role of taurine on normal foetal beta cells in vitro and in vivo. This finding is important because islet cells have been described to have a low proliferative potential, and the production of new beta cells by division normally does not exceed $3 \%$ per day, a figure that rapidly declines after birth [25]. We also show that taurine supplementation compensates in vitro and in vivo for the impaired proliferation of LP islet cells. This could explain at least partially, the recovery observed in endocrine mass, beta-cell mass and islet size of LP pups supplemented with taurine. Dose-dependent effects of taurine on proliferation have been observed in other cells, such as human lymphoblastoid cells and human retinal pigment epithelial cells $[26,27]$ but taurine was found to inhibit vascular smooth muscle cells proliferation in vitro [28].

Apoptosis, in addition to proliferation, is recognized as a major process in modulating the development of the endocrine pancreas [29]. A wave of apoptosis was described in early postnatal stages [29]. This wave of apoptosis occurs also in our control and low protein diet pups with a peak of $6.9 \%$ in control and $8.7 \%$ in LP islet cells, both at 14 days postnatally [4]. Higher apoptotic rate in foetal islets of LP animals persists even after seven days of culture [30]. In our study, taurine supplementation reduced the apoptotic rate of control neonates and normalised the apoptotic rate in LP animals at each age analysed, without modifying the timing of the peak. In support of this, taurine supplemented to the diet of LP nourished dams reduced the apoptosis induced by nitric oxide or interleukin-1 attack in islets of their foetuses [31]. In other investigations, taurine was found to attenuate rat hepatocyte apoptosis and necrosis through inhibition of both nitric oxide and reactive oxygen species [32], and to decrease human endothelial cell apoptosis through its antioxidant effect and regulation of intracellular calcium flux [33, 34]. Several lines of evidence support the thesis that nitric oxide production is an important pathway inducing apoptosis in islet cells [35] and a wave of inducible nitric oxide synthase (iNOS) in neonatal islets correlated with that of apoptosis [20]. However, it seems from our results that the presence of immunoreactive iNOS within beta cells could be related to developmental apoptosis, but it is not related to the increased apoptosis reported in LP islet cells, or to the anti-apoptotic actions of taurine.

Another potential initiator for the increased apoptotic rate in LP islets, and its reduction by taurine, could be the protein Fas, or CD95, the rodent equivalent for human APO-1. It belongs to the TNF-receptor family and is expressed in many cells [36]. Binding of Fas Ligand (FasL) to the receptor results in the transmission of an apoptotic signal. The expression of Fas in islet cells has been shown in rats $[37,38]$ and humans [39]. In our study, similarly to apoptosis, the percentage of islet cells positive for Fas was increased in LP islet cells. Taurine supplementation decreased the immunoreactivity for Fas in control animals especially at 12 and 14 days of age, and in all days analysed for LP islet cells. These results suggest a possible role for Fas in the induction of apoptosis in LP islet cells, and also give a possible hypothesis on a mechanism of action for taurine in the protection from apoptosis of islet cells. Few investigations describe a link between taurine and Fas activity. Fas activation has been reported to induce taurine release, cell shrinkage and DNA fragmentation [40]. Preloading of the cells with taurine inhibited these events [41].

LP foetuses and neonates showed reduced concentrations of IGF-II islet immunoreactivity and of pancreatic expression of IGF-II mRNA [5]. A similar diminution was found in our study between LP and control animals. Taurine supplementation resulted in increased immunopositive islet cells for IGF-II in control and LP islets. IGF-II acts as a survival factor for islet cells [20] and has been shown to stimulate DNA synthesis and to protect islet cells from apoptosis [42, $43,44]$. We suggest, that IGF-II could contribute directly to the normalisation of the proliferative and apoptotic balance, and thereby islet size, induced by taurine supplementation.

This study shows that amongst amino acids which should be available for normal development of foetuses and neonates, adequate taurine concentration is of major importance. Taurine supplementation to a low protein diet reversed many of the morphological and biochemical deficits. Taurine supplementation could be a possibility to counteract the deleterious alterations due to nutritional deficiency on the programming of the metabolic axis in early life.

Acknowledgements We are grateful to the Parthenon Trust, London, UK, the Fond National de Recherche Scientifique, Belgium and the European Union (QLTR-2000-00083) as well as to the Canadian Institutes of Health Research, the Canadian Diabetes Association and the Juvenile Diabetes Research Foundation for financial support.

\section{References}

1. Hales CN, Barker DJP (1992) Type II (non insulin dependent) diabetes mellitus: the thrifty phenotype hypothesis. Diabetologia 35:595-601

2. Snoeck A, Remacle C, Reusens B, Hoet JJ (1990) Effect of low protein diet during pregnancy on the fetal rat endocrine pancreas. Biol Neonate 57:107-118

3. Garofano A, Czernichow P, Breant B (1997) In utero undernutrition impairs rat beta-cell development. Diabetologia 40:1231-1234

4. Dahri S, Snoeck A, Reusens B, Remacle C, Hoet JJ (1991) Islet function in offspring of mothers on low protein diet during gestation. Diabetes 40:115-120 
5. Petrik J, Reusens B, Arany E et al. (1999) A low protein diet alters the balance of islet cell replication and apoptosis in the fetal and neonatal rat and is associated with a reduced pancreatic expression of insulin like growth factor II. Endocrinology 140:4861-4873

6. Reusens B, Remacle C (2000) Effects of maternal nutrition and metabolism on the developing endocrine pancreas. In: Barker DJP (ed) Fetal origins of cardiovascular and lung disease, vol 17. Marcel Dekker Inc, New York, pp 339358

7. Reusens B, Dahri S, Snoeck A et al. (1995) Long term consequences of diabetes and its complications may have a fetal origin: experimental and epidemiological evidences. In: Cowett RM (ed) Nestlé Nutrition Workshop Series, vol 25, Raven Press, New York, pp 187-198

8. Zelikovic I, Chesney RW, Friedman AL et al. (1990) Taurine depletion in very low birth weight infants receiving prolonged total parenteral nutrition: role of renal immaturity. J Pediatr 116:301

9. Malandro MS, Beveridge MJ, Kilberg MS, Novak DA (1996) Effect of low-protein diet-induced intrauterine growth retardation on rat placental amino acid transport. Am J Physiol 271:C295-C303

10. Norberg S, Powell T, Jansson T (1998) Intrauterine growth restriction is associated with a reduced activity of placental taurine transporters. Pediatr Res 44:233-238

11. Huxtable RJ (1992) Physiological actions of taurine. Physiol Rev 72:101-163

12. Sturman GA (1993) Taurine in development. Physiol Rev 73:119-147

13. Bustamante J, Alonson EJ, Lobom V et al. (1998) Taurine levels and localization in pancreatic islets. Adv Exp Med Biol 442:65-69

14. Cherif H, Reusens B, Dahri S et al. (1996) Stimulatory effects of taurine on insulin secretion by fetal rat islets cultured in vitro. J Endocrinol 151:501-506

15. Kulakowski EC, Maturo J (1984) Hyperglycaemic properties of taurine: not mediated by enhanced insulin release. Biochem Pharmacol 33:2835-2838

16. Cherif H, Reusens B, Ahn MT et al. (1998) Effect of taurine on the insulin secretion of islets of fetuses from dams fed a low protein diet. J Endocrinol 159:341-348

17. Mourmeaux JL, Remacle C, Henquin JC (1985) Morphological and functional characteristics of islets neoformed during tissue culture of fetal rat pancreas. Mol Cell Endocrinol 39:237-246

18. Scutte B, Reynders MM, Bosman FT, Blijham GH (1987) Effect of tissue fixation on anti-bromodeoxyuridine immunohistochemistry. J Histochem Cytochem 35:1343-1345

19. Campana D, Coustan-Smith E, Janossy G (1988) Double and triple staining methods for studying the proliferative activity of human $\mathrm{B}$ and $\mathrm{T}$ cells. J Immunol Methods 107:79-88

20. Petrik J, Arany E, McDonald TJ, Hill DJ (1998) Apoptosis in the pancreatic islet cells of the neonatal rat is associated with a reduced expression of insulin-like growth factor II that may act as a survival factor. Endocrinology 139: 2994-3004

21. Sgonc R, Boeck G, Dietrich H, Gruber J, Reicheis H, Wick G (1994) Simultaneous determination of all cell surface antigens and apoptosis. Trends Genet 10:41-42

22. Lim E, Park S, Kim H (1998) Effect of taurine supplementation on the lipid peroxide formation and the activities of glutathione-related enzymes in the liver and islet of type I and II diabetic model mice. In: Shaffer JE et al. (eds) Taurine 3. Plenum Press, New York, pp 99-103
23. Lampson WG, Kramer JH, Schaffer SW (1983) Potentiation of the actions of insulin by taurine. Can J Physiol Pharmacol 61:457-463

24. Hellerström C, Swenne I (1985) Growth pattern of islets in animals. In: Wolk BW, Arquilla ER (eds) The diabetic pancreas. Plenum Press, New York, pp 53-79

25. Kaung HL (1994) Growth dynamics of pancreatic islet cell populations during fetal and neonatal development of the rat. Dev Dyn 200:163-175

26. Gaull GE, Wright CE, Tallan HH (1983) In: Kuriyama K, Huxtable RJ, Iwata H (eds) Sulphur amino acids, biochemical and clinical aspects. Alan Liss, New York, pp 297304

27. Gabrielan K, Wong HM, Ogden TE et al. (1992) In vitro stimulation of retinal pigment epithelium proliferation by taurine. Curr Eye Res 11:481-487

28. Zhang X, Tenner TE, Lombardini JB (1999) Inhibition of rat vascular smooth muscle cell proliferation by taurine and taurine analogues. Biochem Pharmacol 57:1331-1339

29. Scaglia L, Cahill CJ, Finegood DT, Bonner-Weir S (1997) Apoptosis participates in the remodeling of the endocrine pancreas in the neonatal rat. Endocrinology 138:17361741

30. Merezak S, Hardikar A, Yajnik CS, Remacle C, Reusens B (2001) Intrauterine low protein diet increases fetal $\beta$ cell sensitivity to NO and IL-1 $\beta$ : Protective role of taurine. J Endocrinol 171:299-308

31. Remacle C, Merezak S, Reusens B (2000) Taurine supplementation to the low protein diet of the dam or added in vitro prevents the cytotoxic action of interleukin-1 $\beta$ in fetal rat islet. Diabetes Res Clin Pract [Suppl 1]:P615:S153 (Abstract)

32. Redmond HP, Wang JH, Bouchier-Hayes D (1996) Taurine attenuates nitric oxide- and reactive oxygen intermediate-dependent hepatocyte injury. Arch Surg 131:12801287

33. Wang JH, Redmond HP, Watson RW, Condron C, Bouchier-Hayes D (1996) The beneficial effect of taurine on the prevention of human endothelial cell death. Shock 6:331-338

34. Wu QD, Wang JH, Fennessy F, Redmond HP, BouchierHayes D (1999) Taurine prevents high-glucose-induced human vascular endothelial cell apoptosis. Am J Physiol 277:C1229-C1238

35. Zumsteg U, Fvigerio S, Hollander GA (2000) Nitric oxide production and Fas surface expression mediate two independent pathways of cytokine-induced murine beta-cell damage. Diabetes 49:39-47

36. Maria R, Testi R (1998) Fas-FasL interactions: a common pathogenetic mechanism in organ-specific autoimmunity. Immunol Today 19:121-125

37. Harrisson M, Dunger AM, Berg S, Mabley J, John N, Green MHL, Green IC (1998) Growth factor protection against cytokine-induced apoptosis in neonatal rat islets of Langerhans: role of Fas. FEBS Lett 435:207-210

38. Hanke J (2000) Apoptosis and occurence of Bcl-2, Bak, Bax, Fas and FasL in the developing and adult rat endocrine pancreas. Anat Embryol (Berl) 202:303-312

39. Loweth AC, Williams GT, James RFL, Scarpello HB, Morgan NG (1998) Human islets of Langerhans express Fas Ligand and undergo apoptosis in response to interleukin $1 \beta$ and Fas ligation. Diabetes 47:727-732

40. Lang F, Madlung J, Uhlemann AC, Risler T, Gulbins E (1998) Cellular taurine release triggered by stimulation of Fas (CD95) receptor in Jurkat lymphocytes. Pflugers Arch 436:377-383 
41. Lang F, Madlung J, Semen D, Ellory C, Lepple-Wienhues A, Gulbins E (2000) The involvement of caspases in the CD95 (Fas/Apo-1)- but not swelling-induced cellular taurine release from Jurkat T-lymphocytes. Pflugers Arch 440:93-99

42. Hogg J, Hill DJ, Han VKM (1994) The ontogeny of insulin-like growth factor (IGF) and IGF binding protein gene expression in the rat pancreas. Diabetes 36:465-471
43. Rabinovitch A, Quigley C, Russel T, Patel Y, Mintz DH (1982) Insulin and multiplication stimulating activity (an insulin-like growth factor) stimulates islet beta cell replication in neonatal rat pancreatic monolayer culture. Diabetes 31:160-164

44. Hill DJ, Petrik J, Arany E, McDonald TJ, Delovitch TL (1999) Insulin-like growth factors prevent cytokine-mediated cell death in isolated islets of Langerhans from prediabetic NOD mice. J Endocrinol 161:153-165 